\title{
ABOUT FEMALE DEITIES IN THE MYTHOLOGY OF FINNO-UGRIC PEOPLES
}

\author{
Nina Yurchenkova
}

\begin{abstract}
The most widespread female deity in world mythologies is the Goddess of the Earth, known among Finno-Ugric peoples as Mother Earth. Research presumes that the cult of Mother Earth is relatively recent in origin, and somewhat associated with and related to the development of agriculture. Still, the religion of Finno-Ugric peoples comprises abundant other female deities whose help and assistance women can account for when in need. Moreover, among those Finno-Ugric peoples whose tillage culture is less developed, the Goddess of the Earth can sometimes obtain even cosmogonic functions. The article gives an overview of Finno-Ugric female deities, their functions and the ways to sustain the favour of gods.
\end{abstract}

Key words: female deity, fertility goddess, Finno-Ugric mythology, Mother Earth

The most prevalent deity in world mythology is the Goddess of the Earth fertile, giving birth and devouring. This Great Mother combines both the surface of the earth, giving benefits to people, and the world of death underneath. The attaining of immortality in paganism is associated with the cult of the goddess personifying the archetype of motherhood, making it possible for the people to become one with the god.

Among the majority of Finno-Ugrians, it is the figure of the Mother Earth who represents this archetype. Researchers presume that the cult of the goddess, Mother Earth, does not go back to distant history, being of much more recent origin than that of other peoples involved in the cultivation of arable lands, for example the Slavic people. In the case of certain Finno-Ugric peoples (e.g. the Mordvins) the development of the cult of Mother Earth has evidently become more pronounced once agriculture became their prevalent field of subsistence.

In the case of others (e.g. the Khanty and Mansi), natural conditions have added the motif of fertility to the cult, usually expressed in honouring the earth and associated with the meaning of the earth as the giver of life. This motif, however, has been borrowed as the land in these habitats would not provide a vitally necessary and expedient fruit of crops (Karjalainen 1995: 236237). 
The imagination of the Earth as the female primordium of the Universe, the wife of the Sky and the goddess of fertility was most evident in family and calendar customs. The Mari people believed that Mlande Ava (Mother Earth) has the ability to fall pregnant as a woman, at certain periods when it was forbidden to dig the ground, knock, shout or make noise. During Mlande shotchyn, the feast to honour the Mother of Earth, it was not allowed to do any work that would be detrimental for the earth; likewise, it was forbidden to heat stoves, food could be cooked only in the evening, and the bread had to be baked earlier. People had to abstain from walking barefoot on the ground and agricultural activities - ploughing, digging or pounding stakes in the ground were forbidden. Violation of the rule could bring about a relatively harsh punishment: a thunderstorm would beat down the crop or a person could be hit by lighting (Toidybekova 2007: 162).

According to the folk belief of Udmurts, Muzjem-Mumy (Mother Earth) would become angry if land was cultivated at the wrong time, during her sleep. She would not like the digging of holes. The animals sacrificed to Muzjem-Mumy were of dark colour - that of the earth - oxen and sheep: their bones, blood and offal were dug into the ground, and meat was eaten during the feast.

Pursuant to the folk belief of Estonians, the Mother of Earth, spouse of the God of Sky, conceived the crop during sowing and thunderstorm rain.

In Mordva, the earth was revered as a deity, it was personified, with human features and characteristics attributed to her. The songs and incantations reflect the anthropomorphic figure of Mastorava, the Earth Mother, whereas it is underlined that "Mastorava is not beautiful, she has a black face, long nose and thick lips" (Harva 1952: 189).

With regard to Mordvin mythology, there are no direct references to the belief that the Earth was the spouse of the Heaven, however, the imagination that fertility depends on the earth, and also on the main god Verepaz who would symbolise the heaven, was wide-spread. Mordvins say that "Verepaz is our father, Mastorava is our mother."

Karelians honoured Munnutar, the mother of the earth, and approached her as a living being prior to sowing:

Munnutar, mistress of the earth,

Force the tuft to come to life,

Make the ground fertile...

Wake up, earth,
Wake up, meadow,

Let stalks rise here,

Let sprouts emerge here...

(Petrukhin 2003: 82)

In folk tradition, the Earth could cure a person from all diseases, she was asked to protect from evil spirits and witches. People believed that the earth was the main habitat of the dead, the element connecting the world of the dead and that of the living. 


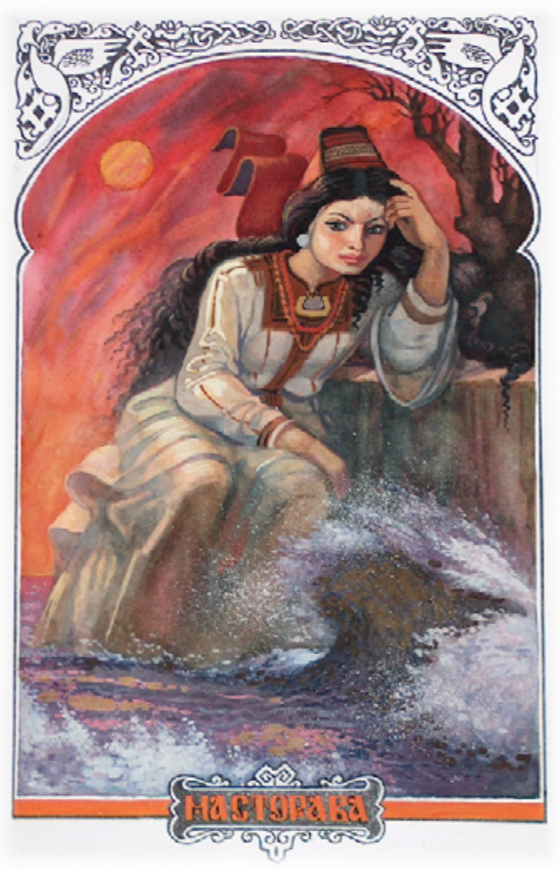

Mastorava - Mother Earth. N. S. Makushkin.

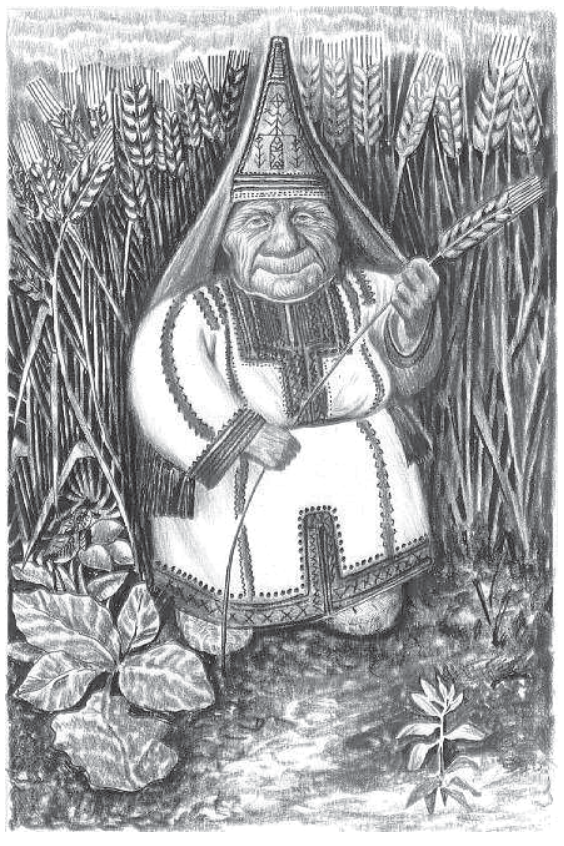

Paks'ava - protector of fields. A. S. Aleshkin.

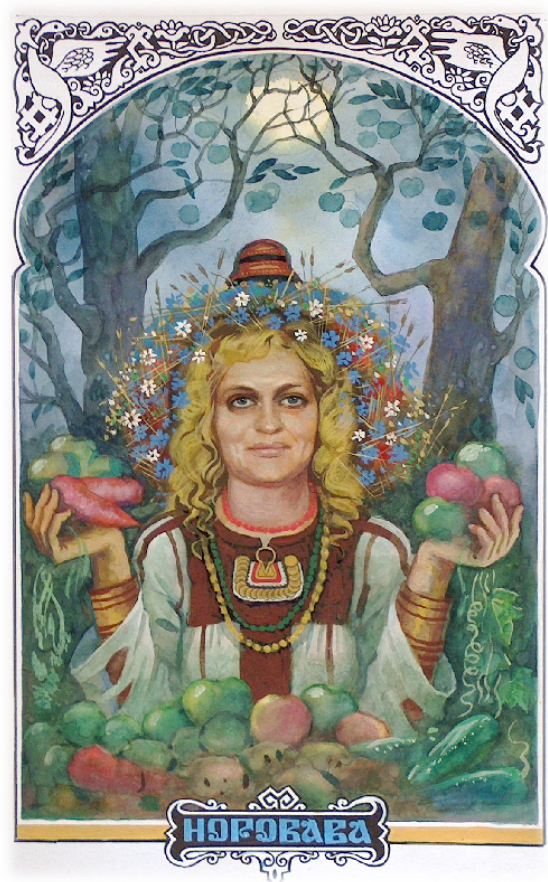

Norovava - Mother Bread. N. S. Makushkin.

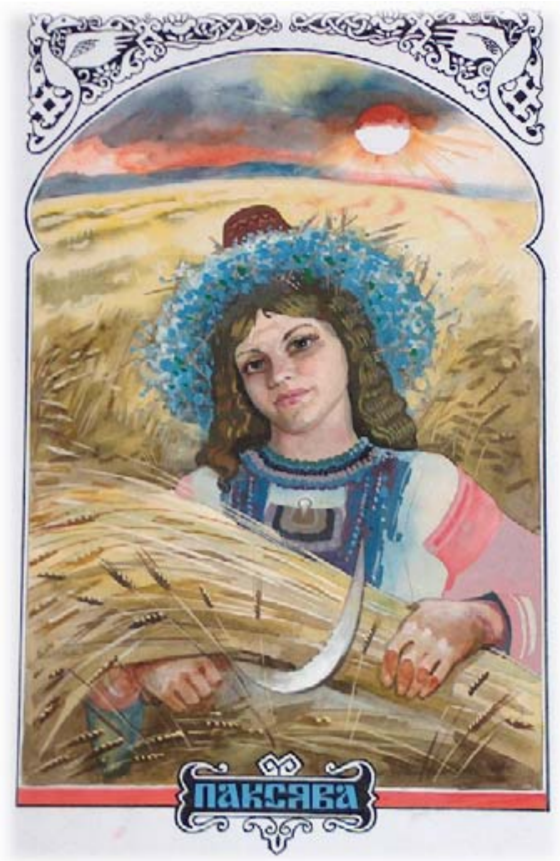

Paks'ava - protector of fields. N. S. Makushkin. 
Differently from the Mother Earth of the Eastern Slavs, personifying the productive primordium and fertility of woman, the Finno-Ugric Earth Mother does not bear such functions. For instance, in Mordvin folk belief, the characteristics absent in Mother Earth Mastorava are attributed to Paks'ava, the protector of fields, who has an immediate connection with the crop, and Mother Bread Norovava, who, in addition, explicitly denotes the field and crop.

Among the Finno-Ugric peoples with scanty land cultivation, the goddess of the Earth sometimes also has cosmogonic functions. The Earth Mother of the Mansi, Kaltashch-ekva (Kaltas-ekva, Ma-ankva, Ioli-Torum-syan) participated in the creation of the world and man: it was indeed Kaltashch-ekva who gave advice to Numi-Torum, to secure the land floating on the surface of the ocean, with a belt of mountains; she was also the one who blew life into the first people.

Kaltashch-ekva, thrown on the earth from heaven, became the Goddess of Earth, and in folk tradition, she is also referred to as "earth with skin", "earth with hair". She was revered as the one protecting from illnesses and giving children. Kaltashch-ekva was considered the ancestress of the Mos people who united the Ob-Ugrians. She was depicted as a female rabbit or goose - the (totem) animal of ancestors, or as a butterfly, the spirit animal. As the ancestor of people, Kaltashch-ekva was believed to assist at childbirth, and to determine the destiny of people: she marked the entire course of life of a person on special sticks. The human fate after death also depended on her - she determined the persons from whose descendants the dead person had to be reborn (Myths 1990: 15).

In the mythology of the Scandinavian Sami, the Mother of Earth, Madderakka, i.e. the spouse of the heavenly god Madderatcha, participates in the creation of man, giving the spirit to the created body: when a boy is born, he is trusted to Uksakka, the daughter of Madderakka, and the newborn girl is given to another daughter, Sarakka. Fertility and the birth of people and animals are under the protection of Sarakka, as is the growth of plants. The third daughter Juksakka protects children and the dwellings of people.

The three daughters of the Earth Mother remind of the three governing goddesses, the Greek Moirae, or the three Old Norse Norns, known in the Balto-Finnic folklore as the ones who determined the destiny of people.

The archetype of motherhood among the Finno-Ugric peoples, revealed in protective deities who have a dense connection with the elements of the earth, is most vivid in Mordvin mythology. The Water Mother, Ved'ava, provides invigorating humidity, she is the protector of love, marriage and childbirth; family, calendar and (particularly) wedding traditions refer to this. Help was sought from the Mother Water not only during the drought, but also when the spouses 
were infertile, or in order to overcome an illness associated with water; brides would call for the Mother Water, praying for happiness in the marriage, the blessing of the goddess, and to have many sons and daughters. On the second day of the wedding, the prayers of the bride were confirmed with offerings in the form of money or a hen drowned in water. An indispensable ritual was to immerse the bride in water - the bride was taken to the riverside straight from the wedding bed. Mordvins believed that this ritual was to contribute to the delivery of children.

Mordvin Ved'ava has certain common traits with mermaids, both with regard to their appearance, functions and disposition - as mermaids, Ved'ava was an anthropomorphic figure, she could appear as a young girl (either naked or in clothes) with long loose hair, and as a dreadful woman with hanging breasts. As with mermaids, water was the home of Ved'ava, and she could affect the destiny of man, fertility and crop yield of fields.

Likewise, water spirits protected motherhood and women's work among the Maris. After wedding, the young wife would give an offering to the Water Mother Vyd Ava: three beads or coins and a cowrie, saying, at the time: "Let it be peaceful for me to come to the water and let the evil not besiege me."

The Udmurts worshipped Gudyr-mumy

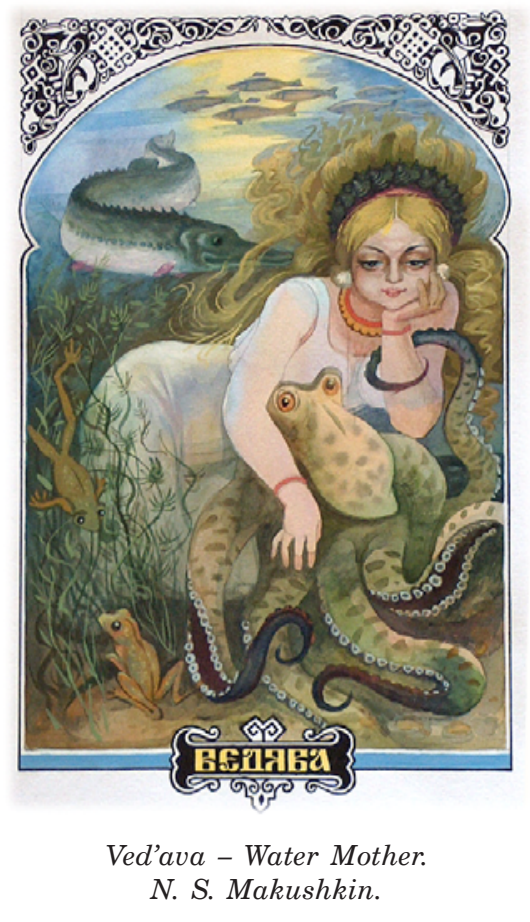
and Invu-mumy (the Mother of Celestial Water), her name was constantly reiterated in prayers and at large ritual gatherings where the gusli-player played a sacred tune about the search of heavenly water, this was accompanied with the ritual lamentation of the people: the tears had to bring about a downpour from heaven. Invu-mumy would also bring luck at childbirth and happiness in the family.

Ban'ava, the Sauna Mother in Mordvin mythology, has similar functions as Ved'ava - she is the protector of parturient women, family and health. The anthropomorphic figure of Ban'ava is a naked woman sitting on sauna platform, combing her long hair. Ban'ava lives on the sauna platform, or, less frequently, in the hearth. She lives there with her family - with children, and his husband Ban'ata. She can also appear in the attic, in infrequent occasions. 


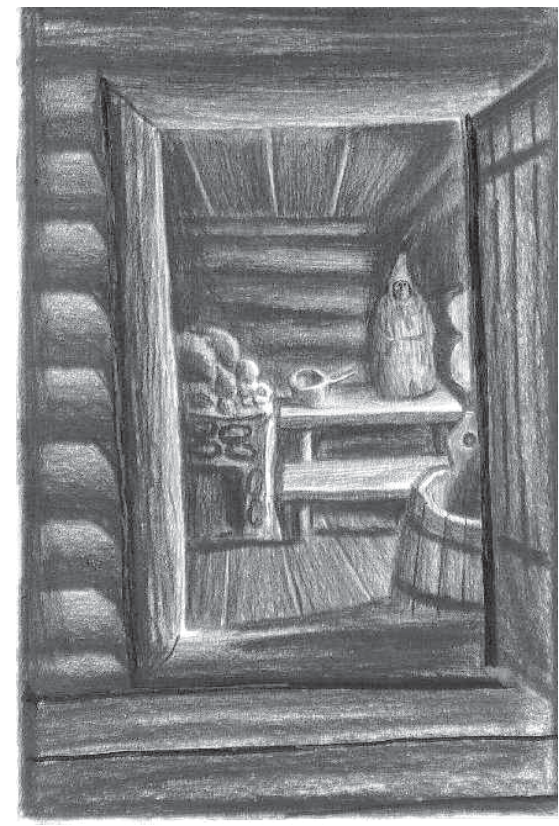

Ban'ava - Sauna Mother. A. S. Aleshkin.

Ban'ava as the protective deity of childbirth, family and health, had an important role in family tradition: at childbirth, wedding, funerals and wakes. The connection of Ban'ava with delivery is clearly traceable as it was indeed in the sauna where midwives assisted at childbirth.

Ban'ava's guardianship of childbirth and family is clearly evident as she also participates in wedding customs. A prenuptial ritual washing takes place in the sauna, and the content of the lamentations targeted at Ban'ava refer to a connection with initiation rites after which the bride is entitled to get married. The semantics of this tradition is very explicit: the bride leaves her virgin spirit to the protector of the sauna, in the sanctuary of ancestors. This act is associated with death. The signs of forthcoming resurrec-

tion can be seen in un-plaiting hair, symbolising transformation in folklore, the assumption of a new shape, rebirth in a new quality.

Among the Mordvins, the Sauna Mother functions as the giver of health as a healer, it is in her capacity to rid people of suffering, but she can also afflict people with a disease. Healing is thought of as expelling the disease, and is practiced in the sauna as this is a place of hygiene, with a curing and magic function. As the Sauna Mother occurs as the guardian of the life cycle of man, and also as the one guiding the future, it is not at all surprising that she also has the capability to forecast the future; she does indeed partially function as the goddess of fate (next to other protective deities) in Mordvian folk belief where there is no separate goddess as such.

Forest Mother, Vir'ava, appears to be the one protecting the fertility of women. In some texts, she also figures as a midwife - indeed, this might be associated with her anthropomorphic figure, huge breasts hanging to the knees or thrown over her shoulders. Vir'ava has the capacity to predict the future: according to one folklore text she had drowned the first newborn, and thrown the second baby in the fire, when assisting at childbirth, and wrapped the third one in swaddling clothes and given this to the mother. She had done this because she could see the future of the babies: "the first one would have drowned 
when growing older, the other one would have burned in a fire, and the mother would have been more devastated than now" (Smirnov 2002: 221).

A number of fairy-tale plots, concerning Vir'ava, narrate of abduction of children and their later return home, referring to her ties with the initiation rite. Vir'ava helps children who have appeared in an unfamiliar environment (lost in the forest or the world beyond) and are tormented, giving them advice. In initiation rites Vir'ava tends to have similar functions as the Russian Baba Yaga; in general, they both look similar, being repulsive, not pleasant: Vir'ava has extremely long legs, or only one leg, one eye on top of her head, her teeth are huge and remind one of harrow spikes; Baba Yaga has one bone leg, she is blind (or her eyes ache), and her

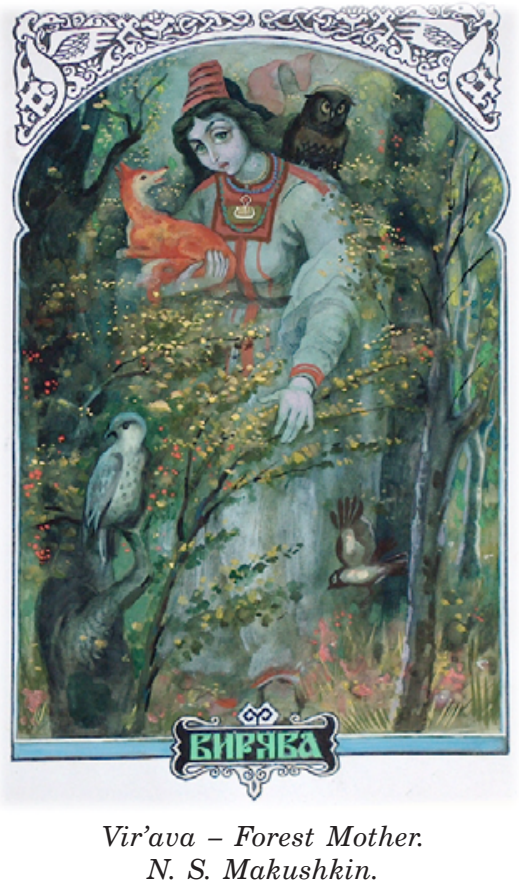
teeth are big and sharp. Both these characters underline certain femininity: large breasts which probably refer to fertility.

The deities complementing the image of a big mother in Mordvin folk belief comprise Kudava, the house fairy, and Yurtava, the farm mother, who protected the surrounding environment, customs and traditions of people and their mode of life. They could foresee the destiny of a person, and could also change and affect this towards a certain direction. The connection with the cult of ancestors and the underworld is more explicit in these deities than the ones discussed above - the presence of Kudava and Yurtava is obligatory at weddings, funerals, wakes, or when placing a cornerstone, building a new house and moving in, etc.

Likewise, similar functions are also attributed to Konga ava, the protector of hearth and stove in Mari folklore - childless women appealed to her for help, and hopes were put on her in case of illnesses that seemed to have occurred during everyday work at the fireside, or when making firewood, fetching water or cooking for the wakes. The protector of hearth was prayed to provide domestic wellbeing during ritual practices concerning the most important phases of human life: at birth, when creating a family, at death and wakes (Toidybekova 2007: 120).

This archetype is also evident in Pugos (Anki-Pugos), the life-giving female deity, of the Eastern Khanty, who protects against diseases and gives children, 
and is also referred to as the Mother of Fire. She was the daughter of NumiTorum (though, in some myths, his mother).

Her dwelling lies far away in the east - beyond seven mountains, seven seas and seven birch forests. With sunbeams - the plaits of the deity - Pugos sends the souls of children, as little birds, into the bosom of the mother. At birth, she grants the power of life (ильт) to the newborn person: for this she needs to touch seven cradles on the golden roof of her dwelling, and do this for seven times. When the baby gurgles in the cradle, this means she/he is talking to Pugos, and therefore, the grown-ups have to be careful not to speak indecently about the spirits while the child is listening. Pugos can punish women for being unfaithful, either with a complicated delivery or by giving birth to a bastard (Petrukhin 2003: 365).

Presumably, this archetype connecting fertility, destiny, marriage and the protection of the hearth in Finno-Ugric female deities, has certain mantic functions. Mother of Earth is the most complete representation of this archetype, having certain typological similarities in the tradition of different peoples. Likewise, the variability and the specific functional features of the archetype originate from the fact that some of her functions are executed by other deities, occurring in parallel in folk belief.

\section{REFERENCES}

Harva, Uno 1952. Die religiosen Vorstellungen der Mordwinen. Folklore Fellows Communications 142. Helsinki: Academia Scientarum Fennica.

Karjalainen, Kustaa Fredrik 1995. Religiia iugorskikh narodov. Tomsk: Izdatel'stvo Tomskogo universiteta.

Myths $1990=$ Mify, predaniia, skazki khantov i mansi. Moskva: Nauka.

Petrukhin, Vladimir 2003. Mify finno-ugrov. Moskva: Astrel'.

Smirnov, Ivan 2002. Mordva: Istoriko-etnograficheskii ocherk. Saransk: Krasnyi Oktiabr'. Toidybekova, Lidiia 2007. Mariiskaia mifologiia. Etnograficheskii spravochnik. IoshkarOla: MPIK. 